\title{
REVIEW OF COURT DECISIONS ON APPEAL AND CASSATION
}

\section{Chebotareva G. V.}

\section{INTRODUCTION}

Until now, in the science of both civil procedural and economic procedural law of Ukraine there is no special study entirely devoted to the Institute of appellate proceedings.

In the legal literature before 1917, an appeal was considered as a request by a party who considers a decision of the court of first instance completely or partially incorrect, for a new examination and a new decision of the case by the court of higher instance. So, the purpose of the appeal is the review, that is, the secondary consideration of the case on the merits as a whole or in part.

The Institute of cassation proceedings in the economic process, which has been operating in Ukraine since June 21, 2001, differs significantly from traditional forms of cassation proceedings. On the one hand, cassation proceedings in the economic process are limited to checking compliance with the norms of substantive and procedural law by lower courts. On the other hand, the part powers of the economic court of cassation instance the lawmakers the right to change the decision of the court of first instance, appellate court, or to revoke them and make new decisions that are not characteristic for classic appeal system, but is inherent in the audit procedure of reviewing judicial acts, distinctive for legislative of number of foreign countries and domestic civil procedure.

Another guarantee of protection of the rights and legitimate interests of legal entities and citizens is the review of judicial decisions of the Supreme economic court of Ukraine by the Supreme Court of Ukraine in the economic process.

\section{Essence and concept of appeal proceedings}

Characteristic features of the appeal may be the following:

1) an appeal shall be made against a court decision that has not entered into force;

2) the case on appeal is transferred to a higher court;

3) the appeal is due to the incorrectness of the decision of the court of first instance, which is, in the opinion of the person who filed the appeal, or in the wrong establishment of actual circumstances or incorrect application of law or incomplete performance by the parties of required material; 
4) the court of appeal, reviewing the case, considers both the factual circumstances and questions of law, that is, has the right to check both the legal and factual sides of the case to the extent that the court of first instance;

5) an appeal may be allowed only once in each case.

This characteristic of the appeal is the most General. However, with the General concept, features and purpose of the appeal, there are special features characteristic of different types of appeal.

Thus, appeal proceedings are a set of actions of the economic court of appeal and persons participating in the case, carried out in order to verify the legality and validity of acts of the economic court of first instance, which have not entered into force and re-examination of the case on the merits.

For the implementation of the appeal proceedings it is necessary to have a number of prerequisites of an objective and subjective nature. The prerequisites for appeal are understood as preconditions for the realization of the right to appeal ${ }^{1}$.

One of the main objective prerequisites for the admissibility of the appeal is the presence of the object on which the appeal is filed. The object of the appeal is the decision of the court of first instance, which has not entered into force and contains, in the opinion of the person filing the appeal, adverse consequences for him of the dispute resolution.

The objective conditions of admissibility of the appeal include compliance with a certain period of appeal. That is, the appeal proceedings cannot arise if the term for the appeal is missed and its restoration was refused.

So, according to Art. 93 of the CPC of Ukraine, the appeal is filed, and the appeal submission is made within ten days from the date of the decision by the local economic court, and if only the introductory and operative parts of the decision were announced at the court session - from the date of signing the decision, issued in accordance with the law. Restoration of the missed deadline for filing an appeal (submission) is possible within three months from the date of the decision of the local economic court.

Determining the appeal period, it is worth considering that during this time, the persons involved in the case are dissatisfied with the court decision, must prepare for its appeal. They must carefully consider what facts, inconsistencies they have not sufficiently identified, justified and therefore not taken into account by the court of first instance. They should as far as possible correct their shortcomings of evidence, Supplement, develop their defense, in connection with which it will be necessary to submit to the court of appeal new explanations, objections, arguments, evidence. In addition, as

\footnotetext{
${ }^{1}$ Borodin M. review of civil cases on appeal. Right of Ukraine. 2004. No. 8.
} 
correctly noted by I. Zaitsev, you need to psychologically prepare for the appeal, make a motivated complaint, which will be quite difficult to do without the help of lawyers, and pay the state fee.

Therefore, in our opinion, it would be more expedient to revise the term of appeal against decisions of the economic court and increase it to one month, as provided in civil proceedings ${ }^{2}$.

It is necessary to agree with the opinion of E. Borisova that the appeal period should meet two main goals:

1) to provide persons involved in the case, the necessary time to prepare for judicial protection;

2) to provide the necessary time to arrive from their place of residence in the city where the court of appeal.

A subjective prerequisite for the admissibility of an appeal is the presence of a certain circle of persons entitled to appeal against the decision of the court of first instance. It is a question of those persons to whom the decision rendered by court of the first instance does harm that is expressed for them in adverse consequences. Such persons may be:

a) persons whose claims submitted to the court of first instance remained wholly or partially dissatisfied;

b) persons who disagree with the reasoning part of the decision. In this regard, those persons who are quite satisfied with the decision taken in their favor cannot appeal against the decision. This provision follows from the requirement of the need for the interested person to have a legal interest in the process, as a prerequisite for participation in this process.

In accordance with article 91 of the code of civil procedure of Ukraine, the parties have the right to file an appeal, and the Prosecutor-an appeal against the decision of the local economic court, which has not entered into force.

Thus, the subjects of the appeal are the persons involved in the case-the parties (plaintiff, defendant), third parties, their representatives and successors, the Prosecutor.

These persons have the right to appeal if:

1) they have a certain legal interest in the case, that is, they are not satisfied with the decision of the court of first instance and intend to defend their claims in the court of appeal;

2) they have procedural capacity. The opponent on the appeal can become only the person in whose favor the decision of the court of the first instance, or its successor.

${ }^{2}$ Shevchuk P. Institute of appeal: experience of settlement in procedural legislation of certain post-Soviet countries. Bulletin of the Supreme Court of Ukraine. 2000. No. 4. 


\section{Initiation of appeal proceedings}

In order to exercise the right of appeal, in addition to procedural prerequisites (bringing a complaint against a decision subject to appeal in accordance with the law; compliance with the appeal period; filing a complaint by a person who has the right of appeal), it is also necessary to comply with a number of formal conditions. One of them is the condition of compliance of the appeal (submission) with the requisites specified in the law ${ }^{3}$.

In accordance with article 94 of the code of civil procedure of Ukraine, the appeal (submission) is filed (made) in writing and must contain:

1) the name of the economic court of appeal to which the complaint is filed (submission);

2) the name of the local economic court that made the decision, the case number and the date of the decision;

3) requirements of the person filing the appeal (representation), and also the bases on which the question of revision of the decision is raised, with reference to the legislation and the materials available in business or presented in addition;

4) the list of documents attached to the complaint (submission).

The appeal shall be signed by the person filing the complaint or his representative. The complaint shall be accompanied by evidence of payment of the state fee and sending a copy of the complaint to the other party in the case.

The person filing the appeal shall send to the other party in the case a copy of the complaint and copies of the documents attached thereto, which the party does not have.

The Prosecutor, who makes the appeal submission, sends to the parties in the case a copy of it and copies of the documents attached to it, which are absent in the case (article 95 of the COD of Ukraine).

A party to the case, having received an appeal (representation), has the right to send a response to it to the appellate instance and to the person who filed the complaint (representation). This review is signed by the person involved in the case, or his representative. A power of attorney confirming his authority to conduct the case shall be attached to the withdrawal signed by the representative.

The recall may be accompanied by documents that have not been provided previously. In this case, the withdrawal shall be accompanied by evidence of the direction of other persons involved in the case, copies of those documents that these persons do not have.

\footnotetext{
${ }^{3}$ Course of civil procedure: Textbook / V. Komarov, V. Bigun, V. Barankova et al.; ed. Kharkiv: Pravo, 2011. 1352 p.
} 
The direction of the response to the appeal - the right of the person participating in business. Be required to submit a comment, the economic court cannot. Therefore, the absence of a response to the appeal (submission) does not prevent the revision of the Decision of the local economic court (article 96 of the CPC of Ukraine). The content of the review applicable rules article $59 \mathrm{EPC}$ of Ukraine, which regulates the content of the statement of defense.

According to Art. 97 of the code of civil procedure of Ukraine, the appeal (representation) is not accepted for consideration and is returned by the appellate economic court if:

1) the appeal (representation) is signed by the person who has no right to sign it, or the person whose official position is not specified;

2) the complaint (submission) is not accompanied by evidence of sending a copy of it to the other party (parties);

3) documents confirming payment of the state duty in the established order and the size are not attached to the complaint;

4) the complaint (submission) is filed after the expiration of the period established for its filing, without a request for the restoration of this period;

5) before making a determination on the acceptance of the complaint (submission) to the proceedings, the person who filed the complaint filed an application for its withdrawal.

A cassation appeal may be filed against the decision to return the appeal (submission).

About acceptance of the appeal (representation) to production the appellate economic court takes out determination in which reports on time and the place of consideration of the complaint (representation).

The resolution is sent to the parties and the Prosecutor who participated in the consideration of the case or entered into consideration of the case (article 98 of the COD of Ukraine).

It is worth paying attention to the omission of the term of appeal. The missed deadline set for filing an appeal may be restored at the request of the party if there are valid reasons ${ }^{4}$.

Only persons entitled to file an appeal may apply to the economic court for the restoration of the missed deadline. The application may be made in a written application or in a complaint and shall be filed simultaneously with their filing. The petition must specify the reasons for missing the deadline for filing an appeal.

\footnotetext{
${ }^{4}$ Shevchuk P. On the creation and operation of appellate courts in the judicial system of Ukraine. Bulletin Of The Supreme Court Of Ukraine. 1998. No. 2.
} 
The petition for restoration of term on filing of the complaint is considered by the judge of appellate instance individually without notification of the persons participating in business before the decision of a question of acceptance of the appeal to production.

Based on the results of the consideration of the petition for the restoration of the missed deadline for filing an appeal, a determination is made. At restoration of the missed term in this definition it can be specified about acceptance of the complaint to production.

The decision to restore the missed deadline is not subject to appeal.

The decision to refuse to restore the missed deadline for filing an appeal may be appealed in cassation.

\section{Procedure for consideration of the case in the appellate instance}

In the appellate instance, cases are reviewed according to the rules of consideration of these cases in the first instance, taking into account the features provided for by law. The economic court of appeal, reviewing the decision on appeal, uses the rules provided to the court of first instance (article 99 of the CPC of Ukraine).

Unlike the court of first instance, the court of appeal hears all cases in a collegial composition.

The session of the court of appeal consists of three interrelated parts: 1) preparatory; 2) consideration of the complaint on the merits; 3) making and announcement of the decision.

In assigned to the case time the presiding officer opens the meeting, announces the membership of the court explains to the persons participating in business, their rights and obligations, determines the order, figures out whether the participants in the economic process of the application, petition, taps to structure of court, expert, and translator, will lead the discussions, contributing to the full and comprehensive clarification of all circumstances of the case, provides in meeting the proper order.

When considering the case in the appellate instance, the economic court considers the case again on the merits on the evidence available in the case and additionally submitted. The court is not bound by the arguments of the appeal and checks the legality and validity of the decision in full, both in the contested and in the non-contested part, regardless of the arguments set out in the appeal.

Additional proofs are accepted by economic court if the applicant has proved impossibility of their representation in court of the first instance for the reasons which are not depending on it.

The appellate instance does not accept or consider new claims that were not presented during the consideration of the case in the first instance. This 
is one of the features of the consideration of cases in the second instance (article 101 of the CPC of Ukraine).

As A. Keilin notes, the possibility of presenting new claims in the appeal proceedings would contradict the principle of procedural economy, since it could turn out that only part of the claims is considered in the court of first instance, while the other part of the claims the parties could reserve for presenting it when considering the case in the court of appeal.

According to K. Malyshev, the principle of immutability of claims has a strictly defined, limited meaning and is that the claim relationship, as the subject of the process and the decision must remain identical throughout the proceedings, so that the court of second instance under the pretext of appeal did not decide the case for a new claim, which can and should be presented in the proper court of first instance 5 .

However, it should be noted that the court of appeal allows the possibility of changing the original requirements. It is a question, for example, about the requirement of payment of percent which size increased during production on business, about recovery of cost of the lost property that makes a case subject, requirements of judicial offset, about decrease or increase in the size of the claim and other.

These claims can be admitted because they do not change the case, are in direct connection with the essence of the dispute and cannot be considered separately from it.

These requirements, as rightly noted A. Zagorovsky, will not prevent the identity of the subject.

New claims may also be made by agreement of the parties, if such agreement does not violate the public procedure of legal proceedings.

Speaking about the new requirements, it should be noted that in this case we are talking only about substantive requirements, in connection with which the rule in question has no relation to the requirements of a procedural nature.

Refusal of the appeal (submission). In accordance with Art. 100 of the civil procedure code of Ukraine, a person who filed an appeal (representation), has the right to refuse it before the decision. The economic court of appeal has the right not to accept the refusal of the complaint if these actions contradict the legislation or violate the rights and interests protected by the law.

About acceptance of refusal of the complaint (representation) the appellate economic court takes out determination if the decision of local economic court is not appealed by other party.

${ }^{5}$ Course of civil procedure: Textbook / V. Komarov, V. Bigun, V. Barankova et al.; ed. Kharkiv: Pravo, 2011. 1352 p. 
Thus, the interested person may exercise his right to refuse the appeal (submission) as follows:

1) the person who filed the appeal may refuse it before the beginning of the oral proceedings;

2) the person who filed the appeal may refuse it until the end of the trial, that is, until the court of appeal makes a decision on the case;

3) refusal of the appeal - the duty of the person who brought the appeal and refused it, to pay to the opposite party all court costs incurred as a result of filing of this complaint. On the issue of reimbursement of expenses, the court of appeal must make a determination.

The term of consideration of the appeal (submission) is established in Art. 102 of the COD of Ukraine and is two months from the date of its receipt in the economic court.

The decision of the appellate instance. Having listened to explanations of the persons participating in business, having investigated available in business and the presented additional proofs, the appellate economic court accepts the resolution.

When making a decision the court is obliged to solve the following questions:

1) full of the court of first instance of the experiments of the circumstances relevant to the case;

2) are the circumstances proven that the court found established;

3) do the conclusions of the court set out in the decision correspond to the circumstances of the case;

4) are the norms of substantive and procedural law not violated, are they correctly applied;

5) whether arguments of the appeal are proved.

According to Art. 105 of the civil procedure code of Ukraine, the decision of the economic court of appeal must be specified:

1) name of the appellate commercial court that considered the appeal, the court, case number and the date of the decision;

2) the name of the parties and the name of the person who filed the complaint (submission);

3) name a local commercial court, whose decision is being appealed, the case number, date of decision, name of the judge (judges);

4) summary of the essence of the decision of the local economic court;

5) the grounds on which the question of revision of the decision is raised;

6) the arguments set out in the response to the appeal (submission); 
7) the circumstances of the case established by the appellate instance, the arguments on which the appellate instance rejects certain evidence, the reasons for the application of laws and other regulations;

8) in case of cancellation or change of the decision of local economic court-arguments on which the appellate instance didn't agree with conclusions of court of the first instance;

9) conclusions on the results of consideration of the appeal (submission);

10)new distribution of court costs in case of cancellation or change of the decision.

The resolution shall enter into force from the date of its adoption.

The decision is sent to the parties in the case within five days from the date of its adoption.

The decision of the appellate instance may be appealed in cassation.

\section{Powers of the court of appeal}

In accordance with article. 103 COD Ukraine appellate instance by results of consideration of the appeal (submission) has the right:

1) to leave the decision of local economic court without changes, and the complaint (representation) - without satisfaction;

2) cancel the decision in whole or in part and make a new decision;

3) cancel the decision in whole or in part and terminate the proceedings or leave the claim without consideration in whole or in part;

4) to change the decision.

The court of appeal leaves the decision of the local economic court unchanged, and the complaint without satisfaction in the event that it comes to the conclusion that the decision made by the court of first instance is lawful and justified, and the motives of the complaint are insignificant. At leaving of the complaint (representation) without satisfaction in the resolution motives on which arguments of the appeal are recognized wrong or not being the basis to cancellation of the decision shall be specified ${ }^{6}$.

Economic procedural legislation of Ukraine does not contain such a power as the transfer of the case for a new trial in the court of first instance. Its absence is due to the nature of the appeal proceedings, adapted for reexamination of the case and the exercise of judicial control by a higher court. Therefore, having convinced that the decision is illegal or unreasonable, the appellate instance should correct the mistakes made by the court of first instance. Introduction in COD of Ukraine of this rule is caused by "procedural economy, aspiration to accelerate consideration of cases and to

\footnotetext{
${ }^{6}$ Borodin M. review of civil cases on appeal. Right of Ukraine. 2004. No. 8.
} 
eliminate unnecessary red tape". Making a new decision is necessary when violations of substantive law or other circumstances of the case affected the final conclusions of the court of first instance on the rights and obligations of the parties.

Termination of proceedings or abandonment of the claim without consideration in whole or in part may take place only on the grounds provided for in articles 80 and 81 of the code of civil procedure of Ukraine. The Commission of these actions shall entail procedural consequences specified in the law.

The right to change the decision of the appellate instance arises under the same conditions as the right to make a new decision. However, this right, unlike the right to make a new decision, can be exercised only when the mistakes made did not affect the final conclusions of the court of first instance on the rights and obligations of the parties. In particular, the change of the decision will be necessary in case of reduction or increase in the amount of the recovered amount. The change may involve not only the operative but also the reasoning of the decision. Thus, to change the decision-means to make corrections in it, do not influence final conclusions of economic court of the first instance about the rights and obligations of the parties.

According to Art. 104 of the civil procedure code of Ukraine, grounds for cancellation or change of the decision of the local economic court:

1) incomplete clarification of the circumstances relevant to the case;

2) lack of evidence of circumstances relevant to the case, which the local court found established;

3) discrepancy of the conclusions stated in the decision of local economic court to circumstances of business;

4) violation or improper application of substantive or procedural law.

Norms of substantive law are considered violated or incorrectly applied if the economic court: a) did not apply the law to be applied; b) applied the law not to be applied; c) misinterpreted the law.

Non-application of the law to be applied takes place in those cases when the court not only does not specify in the decision the norm of substantive law to be applied in this case, but also resolves the case contrary to the norms of the current legislation. This violation is also a case of application by the court of the cancelled law or norms of the regulatory legal act contradicting the current law, or norms of the act accepted with violation of the established order.

The essence of the application of improper law is that the court in deciding the case is not guided by the norm that regulates the disputed legal relationship. Such violation is caused, as a rule, by incorrect qualification of relations of the parties. 
A misinterpretation of the law takes place in cases where the law to be applied is applied, but its meaning is misunderstood, as a result of which the court makes a wrong conclusion about the rights and obligations of the parties in the decision. An example of such a violation is the court's broad or restrictive interpretation of substantive law.

Violation of the norms of substantive law, as a rule, entails a change or cancellation of the decision of the economic court.

Violation or improper application of procedural law may be grounds for cancellation or change of the decision only if this violation led to the adoption of an incorrect decision ${ }^{7}$.

Violation of the rules of procedural law is in any case the basis for the cancellation of the decision of the local economic court, if:

1) the case was considered by the economic court in the illegal composition of the panel of judges;

2) the case is considered by the economic court in the absence of any of the parties not duly informed of the place and time of the court session;

3 ) the economic court decided on the rights and obligations of persons who were not involved in the case;

4) the decision is not signed by any of the judges or is not signed by the judges specified in the decision;

5) the decision was made not by the judges who were part of the panel that considered the case;

6) the decision is made by economic court with violation of rules of subject or territorial jurisdiction, except the cases provided by the law.

The question of whether this or that procedural violation led or could lead to the adoption of an incorrect decision, in each case, is decided by the court of appeal. The same procedural violation, depending on the circumstances of the case, may entail different procedural consequences and does not always lead to the reversal of the decision. Minor procedural violations committed by the court of first instance during the consideration of the case, if they did not or could not influence the final conclusions of the court, are not grounds for revocation of the decision.

\section{Appeals against the decisions of the local economic court}

The norms of economic procedural legislation provide for appeals not only against decisions of economic courts, but also against rulings made by the court of first instance when considering the case on the merits.

${ }^{7}$ Civil process: the Textbook. No./ A. Andrushko, Y. Belousov, G. Stefanchuk, A. Ugrinovskaya et al. Kyiv: Precedent, 2005. 
According to article 106 EPC of Ukraine, local economic court ruling may be appealed before the appellate order in the cases stipulated by the EPC of Ukraine and Law of Ukraine "On restoring debtor's solvency or declaring bankruptcy".

Appeals against the decisions of the local economic court shall be considered in accordance with the procedure established for consideration of appeals against the decision of the local economic court.

Appeals against the decisions of the local economic court may be filed by the parties and other participants in the judicial process.

In cases cancellation of appeal decisions 1) refusal to accept the claim or 2) the application for commencement of bankruptcy proceedings, 3 ) the return of the statement of claim or application for initiation of bankruptcy proceedings, 4) the suspension of the proceedings, 5) the termination of the proceedings, 6) the abandonment of the claim without consideration or 7) abandonment of the application instituting bankruptcy proceedings without consideration, the case is submitted to local economic court.

It is also worth considering that not every ruling of the economic court of first instance can be appealed separately from the decision. Among the definitions there are those that do not directly affect the correctness of the resolution of the case on the merits and appeal them before the decision is not necessary. Therefore, such determinations cannot be appealed separately from decisions ${ }^{8}$.

\section{The nature, value and the right to appeal against}

Cassation proceedings are a stage of the economic process, which involves checking by the economic court the legality of judicial acts that have entered into force.

This stage is characterized by the following features:

1) the objects of cassation appeal are judicial acts that have entered into force, including the appellate instance;

2) cassation proceedings are initiated, as well as appeal proceedings, only on complaints (submission), which must indicate what is the violation or improper application of the law;

3 ) the purpose of cassation proceedings is to verify the legality of judicial acts;

4) the court of cassation is not bound by the limits of the complaint (submission), but checks the legality of judicial acts in General;

5) cassation proceedings shall be carried out only by the Supreme economic court of Ukraine;

\footnotetext{
${ }^{8}$ Emelyanova I. Appellate and cassation review of court decisions in civil proceedings: theoretical and practical aspects. Right of Ukraine. 2004. No. 2.
} 
6) the court of cassation does not consider the case on the merits, does not check the validity of judicial acts, but checks their legality, that is, the correctness of the application of the norms of substantive and procedural law by the court of first and appellate instance.

Cassation proceedings consist of the following stages:

1) violation of cassation proceedings;

2) preparation for consideration of the cassation complaint (submission);

3) judicial proceedings on the cassation complaint and adoption of the resolution.

The right to cassation appeal arises from the date of entry into force of decisions and decisions adopted by economic courts in the first and appellate instances, in the presence of the prerequisites specified in the law. Such prerequisites are: 1) availability of the decision which has entered into force, the decisions taken out by court of the first or appellate instance; 2) reference of subjects of the appeal to number of the persons participating in business.

In accordance with article 107 EPC of Ukraine, the parties in the case have the right to file a complaint, and the Prosecutor cassation representation on the decision of local economic court, which entered into legal force and the decision of the court of appeal. A cassation appeal may also be filed by persons not participating in the case, if the court has made a decision or decision concerning their rights and obligations.

So, we can distinguish the following entities filing a cassation complaint: 1) parties; 2) third parties; 3) the Prosecutor; 4) persons who are not involved in, but on the rights and obligations which the commercial court received the decision or ruling.

The object of the appeal may be: 1) the decision of the commercial court that entered into legal force; 2) the decree of the appellate instance; 3 ) determine the economic court, the possibility of appeal which provided for the CCP, separate from the solution.

Appeal (representation) is fed (introduced) to the Supreme economic court of Ukraine through local or appeal economic court that made the judgment or order, subject to appeal.

The local or appellate economic court which has accepted about the decision or the resolution which is appealed is obliged to submit the complaint (representation) together with business to the Supreme economic court of Ukraine within five days from the date of its receipt ${ }^{9}$.

According to article. 110 COD Ukraine cassation complaint (representation) can be filed (made) within a month from the date of entry of

${ }^{9}$ Civil process: the Textbook. no. / A. Andrushko, Y. Belousov, G. Stefanchuk, A. Ugrinovskaya et al. Kyiv: Precedent, 2005. 
the decision of the local economic court or the decision of the economic court of appeal into force.

The cassation complaint (representation) is submitted (brought) in writing and shall contain:

1) name of cassation instance;

2) the name of the local or appellate economic court, the court decision of which is appealed, the case number and the date of the decision or decision;

3) the name of the person filing the complaint (submission), and the other party (parties) in the case;

4) the requirements of the person who filed the complaint (submission), indicating the essence of the violation or improper application of substantive or procedural law;

5) the list of documents attached to the complaint (submission).

References in the cassation complaint (representation) to unproven circumstances of the case are not allowed.

The cassation complaint shall be signed by the person who filed the complaint or his authorized representative.

The complaint shall be accompanied by evidence of payment of the state fee and sending a copy of the complaint to the other party in the case.

The person who filed the cassation complaint, sends to other party in business of the copy of the cassation complaint and the documents attached to it which are absent at this party. The Prosecutor, who makes a cassation submission, sends to the parties in the case a copy of it and copies of the documents attached to it, which are absent in the case.

The party receiving the appeal (representation), shall be entitled to send a review of cassation and the person who filed the complaint (representation). The absence of a response to the cassation appeal (submission) does not prevent the review of the appealed court decision ${ }^{10}$.

The cassation complaint (representation) is not accepted for consideration and is returned by court if:

1) the cassation complaint (representation) is signed by the person who has no right to sign it, or the person whose official position is not specified;

2) the complaint (representation) is directed differently, than through the local or appellate economic court which made the decision or the resolution;

3 ) the complaint (submission) is not accompanied by evidence of sending a copy of it to the other party (parties) in the case;

4) documents confirming payment of the state duty in the established order and the size are not attached to the complaint;

${ }^{10}$ Civil process: the textbook. allowance / per zag. ed. NATs. UN-t EXT. cases'. Kharkiv: Vid-vo Hark. NATs. UN-t EXT. del, 2009. 266 p. 
5) the complaint (representation) is filed after the expiration of the term established for its filing, without a request for restoration of the term or such request is rejected;

6) the complaint (submission) does not specify the essence of the violation or improper application of substantive or procedural law;

7) before the direction of determination on acceptance of the complaint (representation) to production from the person who submitted the complaint (representation), the statement for its withdrawal arrived.

About return of the cassation complaint (representation) the definition is taken out.

After elimination of the above circumstances, the party in the case has the right to appeal again, and the Prosecutor to make cassation representation in the General order (Art. 111-3 COD of Ukraine).

About acceptance of the cassation complaint (representation) about production the court takes out definitions in which the time and the place of consideration of the complaint (representation) is reported. Orders are sent to all participants in the trial.

\section{Procedure for consideration of the cassation complaint (submission)}

In cassation instance the complaint (representation) is considered by rules of consideration of business in court of the first instance without considering the procedural actions connected with establishment of circumstances of business and their proof.

The cassation instance uses the procedural rights of the court of first instance exclusively for checking the legal assessment of the circumstances of the case and the completeness of their establishment in the decision or decision of the economic court.

Consideration of the complaint by the cassation instance consists of three interrelated parts: 1) preparatory; 2) consideration of the cassation complaint on the merits; 3) making and announcement of the cassation decision.

In the preparatory part of the hearing, the court of cassation as court of first instance must decide 1) whether the case be dealt with in this part of judges, 2) whether the proceedings in the absence of persons who do not appear involved in the case; 3) explain to the persons participating in business, their rights and responsibilities and to resolve their stated application.

Consideration of the cassation complaint (representation) is carried out by three judges of economic court and begins with: 1) the report of the presiding or one of judges then the cassation instance; 2) hears the persons participating in business, and their representatives. Having listened to 
explanations of the persons participating in business, the court should; 3) familiarize with additional materials.

Reviewing in the order of judicial decisions, the cassation instance on the basis of the established factual circumstances of the case checks the application by the court of the first or appellate instance of the norms of substantive and procedural law ${ }^{11}$.

The cassation instance has no right: 1) to establish or consider as proved circumstances which were not established in the decision or the resolution of economic court or are rejected by it; 2) to solve a question of reliability of this or that proof; 3) about advantage of one proofs before others; 4) to collect new proofs or in addition to check proofs.

In cassation instance the requirements which were not a subject of consideration in court of the first instance (Art. 111-7 of COD of Ukraine) are not accepted and are not considered.

In cassation instance, as in appeal, and in the court of first instance, the principle of competition. The content of this principle is enshrined in article 111-6 of the COD of Ukraine. According to this article, a person who has filed a cassation complaint (submission) has the right to refuse it before the cassation instance makes a decision.

However, the cassation instance has the right not to accept the refusal of the complaint if these actions contradict the legislation or violate the rights and interests protected by the law.

About acceptance of refusal of the complaint (representation) the cassation instance takes out determination if the decision or the resolution of economic court is not appealed by other party.

Term of consideration of the cassation complaint (submission). The cassation complaint (representation) is considered within two months from the date of receipt of the case together with the cassation complaint (representation) in the Supreme economic court of Ukraine.

The decision of cassation instance. By results of consideration of the cassation complaint (representation), the court accepts the resolution that has to consist of 1) introductory, 2) descriptive, 3) motivational and 4) resolute parts.

According to article. 111-11 COD Ukraine, the resolution must be specified:

1) the name of the cassation instance, the composition of the court, the case number and the date of the decision;

2) the name of the parties and the name of the person who filed the cassation complaint (representation);

\footnotetext{
${ }^{11}$ Course of civil procedure: Textbook / V. Komarov, V. Bigun, V. Barankova et al.; ed. Kharkiv: Pravo, 2011. 1352 p.
} 
3) the name of the local economic court or the economic court of appeal, decision, ruling of which carious, case number, date of decision, decision, the name of the judge (judges);

4) summaries of decisions of local economic court, the decisions of the appellate commercial court;

5) the grounds on which the decision, the resolution is appealed;

6) the arguments set out in the response to the appeal (submission);

7) the reasons for which the cassation instance does not apply the laws and other regulatory legal acts referred to by the parties, as well as the laws and other regulatory legal acts that guided the court in making the decision;

8 ) in case of cancellation or change of the decision, the resolution, motives on which the cassation instance didn't agree with conclusions of court of the first or appellate instance;

9) conclusions on the results of consideration of the cassation complaint (submission);

10)actions to be performed by the parties and the court of first instance in case of cancellation of the decision, decision and transfer of the case for new consideration;

11)new allocation of court costs in case of cancellation or change of the decision.

The resolution shall enter into force from the date of its adoption. The decision is sent to the parties in the case within five days from the date of its adoption.

It should be noted that the instructions contained in the decision of the cassation instance are mandatory for the court of first instance at the new hearing of the case. However, the decision of cassation instance cannot contain instructions on 1) reliability or unreliability of this or that proof, 2) about advantages of one proofs before others, 3) about what norm of the material right has to be applied and what decision has to be made by results of new consideration of business (Art. 111-12 of COD of Ukraine).

According to the current legislation, decisions of the economic court may be appealed in cassation, but in cases expressly provided for in the CPC of Ukraine. The economic procedural legislation does not contain rules that cassation check can take place only after the address of interested persons in appellate instance. Therefore, the rules of the COD of Ukraine, providing for the right to appeal against decisions, after the expiration of the term for appeal or refusal to satisfy the complaint are equally applicable to the cassation instance.

Appeal against determination of local or appeal economic court considered in the order provided for the consideration of cassation complaints to the decision of local economic court, the appellate commercial court. 
Appeal against determination of local or appeal economic court can be filed by parties and other participants in the judicial process provided for GIC Ukraine and Law of Ukraine "On restoring debtor's solvency or declaring bankruptcy".

In case of cancellation by the court of cassation decisions of 1) refusal to accept the claim or application for initiation of bankruptcy proceedings, 2) about returning of the statement of claim or application for initiation of bankruptcy proceedings, 3) the suspension of the proceedings, 4) the termination of the proceedings, 5) the abandonment of the claim without consideration or without the abandonment of the application for proceedings on the bankruptcy case, the case is referred to the court of first instance (article 111-13 HPK of Ukraine).

\section{Powers of court of cassation instance at consideration of the case}

Powers of court of cassation instance are defined in Art. 111-9 of COD of Ukraine according to which cassation instance by results of consideration of the cassation complaint (representation) has the right:

1) to leave the decision of the first instance or the decision of the appellate instance without changes, and the complaint (representation) without satisfaction;

2) cancel the decision of the first instance or the decision of the appellate instance in whole or in part and make a new decision;

3) cancel the decision of the first instance or the decision of the appellate instance and transfer the case to the court of first instance for a new hearing if the court has committed violations provided for by the CPC of Ukraine;

4) cancel the decision of the first instance, the decision of the appellate instance in whole or in part and terminate the proceedings or leave the claim without consideration in whole or in part;

5) change the decision of the first instance or the decision of the appellate instance;

6) to leave in force one of the earlier decisions or resolutions.

The appeal court leaves the decision of first instance or the appellate instance without change, and the complaint (submission) dismissed if it is established that the court of first or appellate instance when considering the case correctly applied the substantive and procedural law. Leaving the complaint without satisfaction, the court of cassation instance in its determination must indicate the reasons for which the arguments of the complaint were rejected ${ }^{12}$.

${ }^{12}$ Emelyanova I. Appellate and cassation review of court decisions in civil proceedings: theoretical and practical aspects. right of Ukraine. 2004. No. 2. 
The court of appeal may reverse the decision of first instance or the appellate court fully or in part and adopt a new decision if the first or appeal instance of circumstances of the case were established fully and correctly, but there was a mistake in the application of substantive law.

The decision of the first instance or the appellate instance are subject to cancellation, and business transfer on new consideration in court of the first instance, if the decision or ruling is unfounded. The decision or the resolution is recognized unreasonable if: 1) the circumstances having value for business are incomplete clarified; 2) the circumstances having value for business the economic court considered established, are not proved; 3) the conclusions of court stated in the decision do not correspond to circumstances of business.

Thus, the basis for cancellation or change of the decision of local or appellate economic court or the decision of appellate economic court is violation or wrong application of norms of material or procedural law.

According to Art. 111-10 of the code of civil procedure of Ukraine, violation of procedural law is in any case the basis for cancellation of the decision of the local or the decision of the economic court of appeal, if:

1) the case was considered by the court in the illegal composition of the panel of judges;

2) the case is considered by the court in the absence of any of the parties not properly notified of the time and place of the court session;

3 ) the economic court made a decision or resolution concerning the rights and obligations of persons who were not involved in the case;

4) the decision or the resolution is not signed by any of judges or signed not by those judges who are specified in the decision or the resolution;

5) the decision was not made by the judges who were part of the panel that considered the case;

6) the decision adopted by the economic court in violation of the rules of substantive or territorial jurisdiction, except for the cases stipulated by the law (part 4, article 17 GIC Ukraine - if, after recusal of judges it is impossible to consider the case in the commercial court, to the jurisdiction which referred the case, the Chairman of the Supreme economic court of Ukraine or his Deputy have the right to request any business that you have in the production of local economic court, and to submit it for consideration in another local court).

\section{CONCLUSIONS}

Cassation proceedings under the current arbitration procedural legislation is a new mechanism for verifying the legality of judicial acts and has no analogues in the procedural legislation of other States. A fairly short period 
of activity of the courts of cassation instance showed that such a mechanism really contributes to the correct solution of economic disputes and protection of the rights and legitimate interests of organizations and citizens.

\section{SUMMARY}

The article reveals the essence and the concept of appeal to initiate appellate proceedings, order the proceedings in appellate court powers of appellate court appeal on the definition of local economic court, in cassation proceedings, procedure for consideration of cassation complaints (representations) of the powers of the court of cassation in the proceedings

\section{REFERENCE}

1. Civil process: the textbook. allowance / per zag. ed. NATs. UN-t EXT. cases'. Kharkiv: Vid-vo Hark. NATs. UN-t EXT. del, 2009. 266 p.

2. Civil process: the Textbook. no. / A. Andrushko, Y. Belousov, G. Stefanchuk, A. Ugrinovskaya et al. Kyiv: Precedent, 2005.

3. Course of civil procedure: Textbook / V. Komarov, V. Bigun, V. Barankova et al.; ed. Kharkiv: Pravo, 2011. 1352 p.

4. Emelyanova I. Appellate and cassation review of court decisions in civil proceedings: theoretical and practical aspects. right of Ukraine. 2004. No. 2.

5. Shevchuk P. Institute of appeal: experience of settlement in procedural legislation of certain post-Soviet countries. Bulletin Of The Supreme Court Of Ukraine. 2000. No. 4.

6. Shevchuk P. On the creation and operation of appellate courts in the judicial system of Ukraine. Bulletin of The Supreme Court Of Ukraine. 1998. No. 2.

7. Borodin M. review of civil cases on appeal. right of Ukraine. 2004. No. 8.

\section{Information about the author:} Chebotareva G. V., Doctor of Law, Professor, Professor at the Department of Administrative,

Criminal Law and Procedure, International University of Business and Law 37-A, 49 HGD str., Kherson, 73040, Ukraine 